This is the author's final, peer-reviewed manuscript as accepted for publication. The publisher-formatted version may be available through the publisher's web site or your institution's library.

\title{
Application of Rosgen's BANCS model for NE Kansas and the development of predictive streambank erosion curves
}

Christopher K. Sass, Tim D. Keane

\section{How to cite this manuscript}

If you make reference to this version of the manuscript, use the following information:

Sass, C. K., \& Keane, T. D. (2012). Application of Rosgen's BANCS model for NE Kansas and the development of predictive streambank erosion curves. Retrieved from http://krex.ksu.edu

\section{Published Version Information}

Citation: Sass, C. K., \& Keane, T. D. (2012). Application of Rosgen's BANCS model for NE Kansas and the development of predictive streambank erosion curves. Journal of the American Water Resources Association, 48(4), 774-787.

Copyright: $\odot 2012$ American Water Resources Association

Digital Object Identifier (DOI): doi:10.1111/j.1752-1688.2012.00644.x

Publisher's Link: http://onlinelibrary.wiley.com/doi/10.1111/j.17521688.2012.00644.x/full

This item was retrieved from the K-State Research Exchange (K-REx), the institutional repository of Kansas State University. K-REx is available at http://krex.ksu.edu 


\title{
Application of Rosgen's BANCS model for NE Kansas and the development of predictive streambank erosion curves
}

\author{
Dr. Christopher K. Sass, Research Associate \\ Department of Landscape Architecture / Regional \& Community Planning \\ 302A Seaton Hall, Kansas State University, Manhattan, KS, 66506 \\ Email: csass@k-state.edu \\ Dr. Tim D. Keane, Professor \\ Department of Landscape Architecture / Regional \& Community Planning \\ 302A Seaton Hall, Kansas State University, Manhattan, KS, 66506 \\ Email: whisker@k-state.edu
}

\begin{abstract}
Sedimentation of waterways and reservoirs directly related to streambank erosion threatens freshwater supply. This study sought to provide a tool that accurately predicts annual streambank erosion rates in NE Kansas. Rosgen $(2001,2006)$ methods were employed and 18 study banks were measured and monitored from 2007 through 2010 (May-June). Bank profiles were overlaid to calculate toe pin area change due to erosional processes. Streambanks experienced varied erosion rates from similar Bank Erosion Hazard Index (BEHI)-Near Bank Stress (NBS) combinations producing $\mathrm{R}^{2}$ values of 0.77 High-Very High BEHI rating and 0.75 Moderate BEHI rating regarding predictive erosion curves for NE Kansas. Moderate ratings demonstrated higher erosion rates than High-Very High ratings and BEHI trend lines intersected at lower NBS ratings, suggesting a discrepancy in the fit of the model to conditions in the NE Kansas region. BEHI model factors were evaluated and assessed for additional influences exerted in the region. Woody vegetation adjacent to the stream seemed to provide the most variation in erosion rates. This study's findings allowed us to calibrate and modify the existing BEHI model according to woody vegetation occurrence levels along streambanks with high clay content. Modifications regarding vegetation occurrence of the BEHI model was completed and the results of these modifications generated new curves resulting in $\mathrm{R}^{2}$ values of 0.84 High-Very High BEHI and 0.88 Moderate BEHI ratings.
\end{abstract}

Key Terms: Erosion prediction, BANCS model, Rosgen, Streambank vegetation, Streambank erosion

\section{Introduction}

Worldwide, sediment is one of the most pervasive non-point source pollutants of freshwater (Boggess et al. 1980; US-EPA, 2009) and it is anticipated by 2020 that 36 states will be experiencing freshwater shortages, some will be extreme (Rogers, 2008; USDA, 2010). Up to $80 \%$ of total sediment loading in streams is directly related to streambank erosion (Bull, 1997; Simon and Darby, 1999; Sekely et al. 2002; Evans et al. 2006; Fox et al. 2007) resulting in subsequent deposition of sediment. Impacts include:

- Sedimentation of reservoirs and waterways (Beach, 1994; Hargrove et al. 2010).

- Loss of water storage capacity in reservoirs (Beach, 1994; Williams \& Smith, 2008; Hargrove et al, 2010).

- Higher water treatment costs (Boggess et al. 1980; Williams \& Smith, 2008).

- Increased ambient water temperature (Naiman \& Decamps, 1997).

- Decreased dissolved oxygen in streams (Ringler \& Hall, 1975).

- Loss of stream habitat and biotic diversity (Odum, 1971; Naiman \& Decamps, 1997).

- Decreased aesthetic and recreational value or potential value (Riley, 2008; Williams \& Smith, 2008).

- Increased bank erosion and channel instability (Rosgen, 1996; Knighton, 1998).

- Increased flooding potential (Thorne, 1999). 
These impacts are environmentally harmful, long lasting and unfortunately, more costly to remediate than prevent. Thus, it is imperative to study stream channel sediment sources and understand streambank erosional processes, which may then allow us to mitigate a portion of the sediment pollution of our freshwater resources.

The goal of the work described here was to provide a tool that can accurately predict annual streambank erosion rates and sediment contributions from channel banks in Northeast Kansas. In addition, evaluate the efficacy of Rosgen (2006) methodology in developing streambank erosion prediction curves for Midwestern streams. Once developed, it was expected that these erosion prediction curves could be extrapolated to similar hydrophysiographic regions. Streambank erosion predictive models are of great utility in that they allow quick and accurate estimates of sediment contributions from streambanks and development of watershed sediment budgets. Regarding stream rehabilitation, these curves would allow us to assess and predict streambank problem areas, bank retreat rates, and are an integral part of site inventory and analysis for stream restoration and stabilization design. These predictive curves may also help in setting United States Environmental Protection Agency (US-EPA) water quality standards for sediment, known as Total Maximum Daily Loads (TMDLs). Finally, building a consistent library of erosion rates from different ecoregions across the country will only strengthen scientific study of fluvial processes.

\section{Study Area Description}

The Black Vermillion watershed $\left(1062 \mathrm{~km}^{2}\right)$ is located in Northeastern Kansas, specifically Marshall County, Kansas, and Nemaha County, Kansas (Figure 1). The Black Vermillion river flows westward to the Big Blue River and ultimately empties into Tuttle Creek Reservoir, a multi-use reservoir maintained by the United States Army Corps of Engineers (US-COE), northeast of Manhattan, Kansas. Tuttle Creek Reservoir is approximately $49.4 \mathrm{~km}^{2}$ in size and swells to $214.8 \mathrm{~km}^{2}$ during full flood capacity (USCOE, 2011). The Black Vermillion watershed lies in the glaciated region of Kansas, northeast of the Flint Hills Ecoregion. Three sub-watersheds from the Black Vermillion watershed were selected for study: Irish Creek, Black Vermillion Main Stem, and North Fork (Figure 2). These sub-watersheds were selected due to varied land uses and conservation practices, varied temporal and structural channel modification, and varied riparian corridor management. Each sub-watershed included three study reaches, for a total of nine study reaches (Figure 2). For each study reach, two study banks (eighteen total) were monumented, profiled (2007) and re-profiled through 2010. 
Figure 1. Black Vermillion watershed located in NE Kansas between the Flint Hills and Glaciated Plains Region.

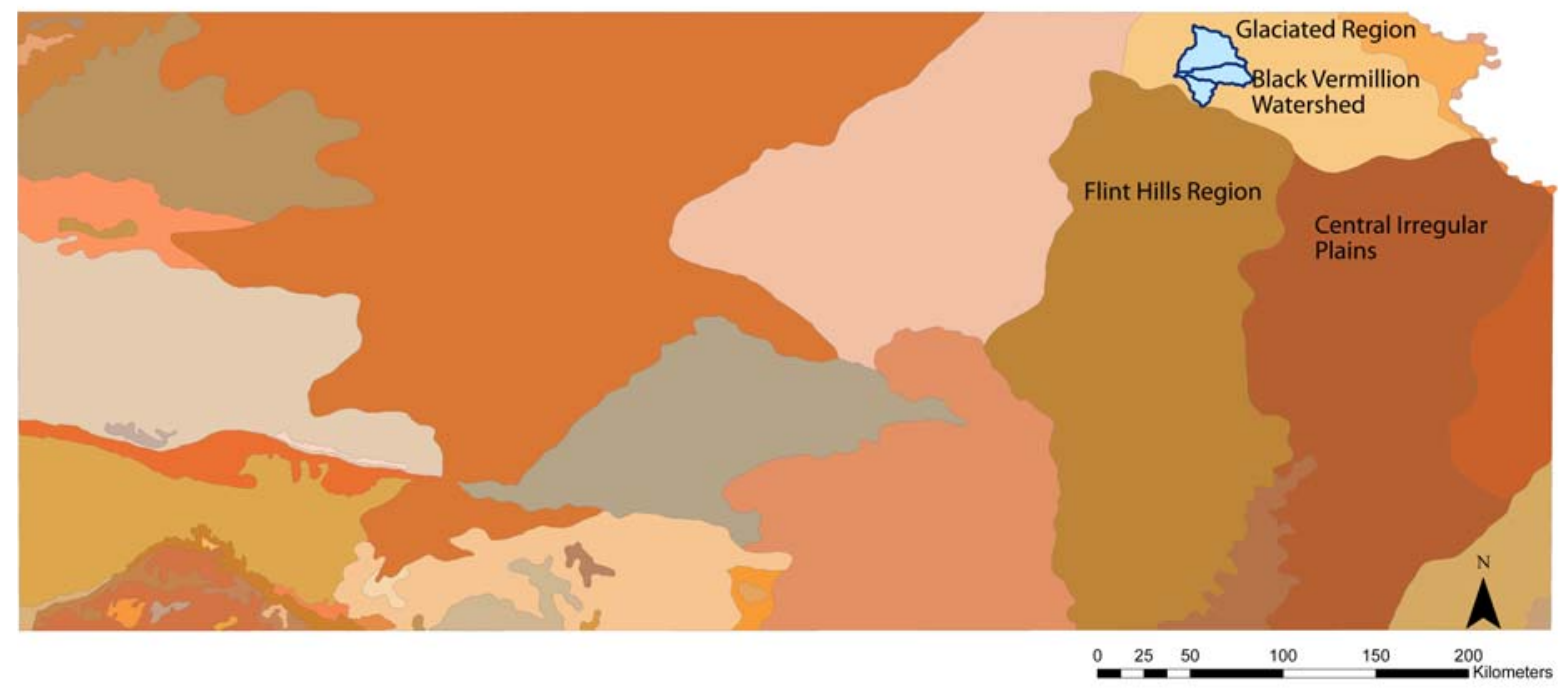

Figure 2. Black Vermillion watershed located in NE Kansas between the Flint Hills and Glaciated Plains. Squares indicate study reach sites.

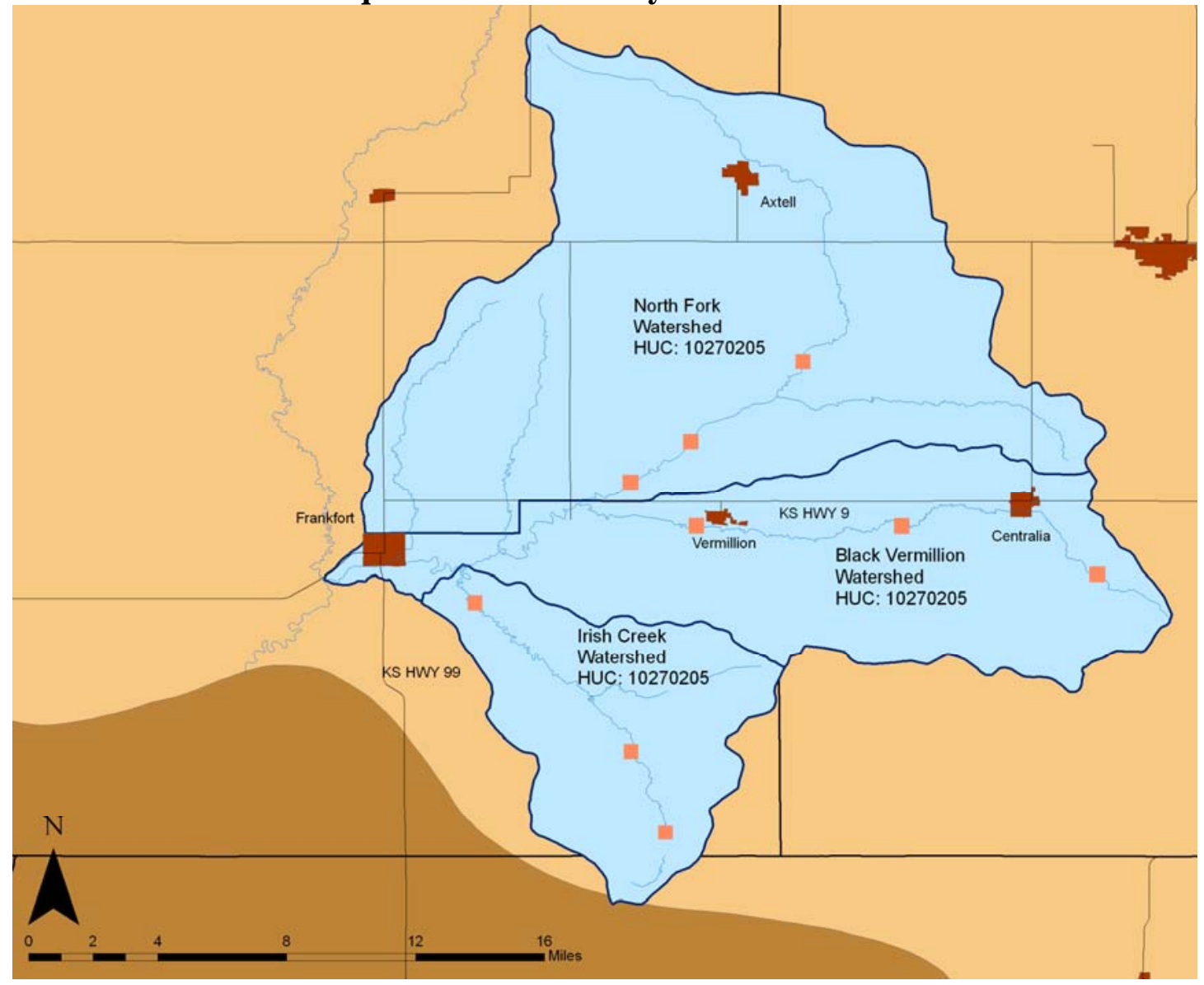

Two physiographic regions influence the study area, the glaciated region of Kansas and the Flint Hills Uplands. These physiographic regions differ in surface geology but 
experience similar climates generating similar plant communities. Geologic formation of underlying bedrock is similar between the two regions since the area was once an inland sea, the last sea existing approximately 270 million years ago. Alternating shale and limestone layers underlying glacial till in the glaciated region dip slightly to the northwest influencing the landscape surface topography; till depths range from $30.5 \mathrm{~m}$ to 122m (Walters, 1954; Aber, 2007a). No glacial till covers the Flint Hills' tilted shale and limestone layers, providing a different hydrophysiographic region, thus differing hydrologic controls. Between the two regions, the Flint Hills and glaciated plains, lies a transition zone where both regions influence local hydrology and ecology, similar to an ecotone. This transition zone mostly influences the western portion of the Irish Creek sub-watershed most while both the Black Vermillion Main Stem and North Fork are heavily influenced by glacial till.

Soils adjacent to channels in the watershed were formed from alluvium and are rich in clay content. Table 1 illustrates major soil properties adjacent to each stream reach throughout the watershed.

Table 1. Soil names and properties adjacent to study stream reaches (NRCS, 2010).

\begin{tabular}{|c|c|c|c|c|c|c|}
\hline Location & Soil Name & $\begin{array}{l}\text { Parent } \\
\text { Material }\end{array}$ & $\begin{array}{l}\text { Percent } \\
\text { Clay }\end{array}$ & $\begin{array}{l}\text { Liquid } \\
\text { Limit }\end{array}$ & $\begin{array}{l}\text { Bulk } \\
\text { Density }\end{array}$ & $\begin{array}{l}\text { Minor } \\
\text { Association }\end{array}$ \\
\hline MS1 & $\begin{array}{l}\text { Kennebec Silt } \\
\text { Loam }\end{array}$ & $\begin{array}{l}\text { Fine-silty } \\
\text { alluvium }\end{array}$ & $25.4 \%$ & $40.5 \%$ & $1.37 \mathrm{~g} / \mathrm{cm}^{3}$ & Wabash \\
\hline MS2 & $\begin{array}{l}\text { Kennebec Silt } \\
\text { Loam }\end{array}$ & $\begin{array}{l}\text { Fine-silty } \\
\text { alluvium }\end{array}$ & $25.4 \%$ & $40.5 \%$ & $1.37 \mathrm{~g} / \mathrm{cm}^{3}$ & Wabash \\
\hline MS3 & $\begin{array}{l}\text { Nodaway Silt } \\
\text { Loam }\end{array}$ & $\begin{array}{l}\text { Calcareous fine- } \\
\text { silty alluvium }\end{array}$ & $23 \%$ & $35.3 \%$ & $1.30 \mathrm{~g} / \mathrm{cm}^{3}$ & Wabash, Aquolls \\
\hline NF1 & $\begin{array}{l}\text { Kennebec Silt } \\
\text { Loam }\end{array}$ & $\begin{array}{l}\text { Fine-silty } \\
\text { alluvium }\end{array}$ & $25.4 \%$ & $40.5 \%$ & $1.37 \mathrm{~g} / \mathrm{cm}^{3}$ & Wabash \\
\hline NF2 & $\begin{array}{l}\text { Wabash silty } \\
\text { clay loam }\end{array}$ & Clayey alluvium & $47.1 \%$ & $62.6 \%$ & $1.35 \mathrm{~g} / \mathrm{cm}^{3}$ & none \\
\hline NF3 & $\begin{array}{l}\text { Nodaway silt } \\
\text { loam }\end{array}$ & $\begin{array}{l}\text { Calcareous fine- } \\
\text { silty alluvium }\end{array}$ & $23 \%$ & $35.3 \%$ & $1.30 \mathrm{~g} / \mathrm{cm}^{3}$ & Wabash, Aquolls \\
\hline IC1 & $\begin{array}{l}\text { Kennebec Silt } \\
\text { Loam }\end{array}$ & $\begin{array}{l}\text { Fine-silty } \\
\text { alluvium }\end{array}$ & $25.4 \%$ & $40.5 \%$ & $1.37 \mathrm{~g} / \mathrm{cm}^{3}$ & Wabash \\
\hline IC2 & $\begin{array}{l}\text { Kennebec Silt } \\
\text { Loam }\end{array}$ & $\begin{array}{l}\text { Fine-silty } \\
\text { alluvium }\end{array}$ & $25.4 \%$ & $40.5 \%$ & $1.37 \mathrm{~g} / \mathrm{cm}^{3}$ & Wabash \\
\hline IC3 & $\begin{array}{l}\text { Wabash silty } \\
\text { clay loam }\end{array}$ & Clayey alluvium & $47.1 \%$ & $62.6 \%$ & $1.35 \mathrm{~g} / \mathrm{cm}^{3}$ & none \\
\hline
\end{tabular}

Note: MS = Black Vermillion Main Stem, NF = North Fork and IC = Irish Creek. The number corresponds to the reach number with 1 representing the upper most reach and 3 representing the lowest reach on the stream (Figure 2).

The climate in northeast Kansas is considered continental with an average precipitation of approximately $81-89 \mathrm{~cm}$ per year. In terms of precipitation, the area enjoys a water surplus providing water movement to stream channels via overland and subsurface flows after evapo-transpiration and vegetative uptake of water (Aber, 2007b). Most precipitation falls during the growing season, April through September (Oznet, 2008) and produces runoff during and after storm events. Annual precipitation amounts varied over the study period (May 2007 through July 2010) ranging from near average (87.6cm) to $30.4 \mathrm{~cm}$ above average (Table 2). Notice that 2007 exceeds the annual precipitation 
average by more than one standard deviation of $20.4 \mathrm{~cm}(30.9 \mathrm{~cm})$. In contrast during June of 2010, the Frankfort gage received $27.4 \mathrm{~cm}$ which exceeded the 50-year average for the month by more than $15.2 \mathrm{~cm}$ alone. There were no more than three days in a row without rainfall of $0.8 \mathrm{~cm}$ or less for the month of June 2010. Even though 2010 was drier than average, the month of June was an anomaly compared to many years. As precipitation does not fall evenly throughout a watershed during a storm event, a mean total was calculated.

Table 2. Precipitation data for the Black Vermillion Watershed area.

\begin{tabular}{|l|l|l|l|l|}
\hline Year & Centralia (Goff) & Frankfort & Lillis & Watershed Mean \\
\hline $\mathbf{2 0 0 7}$ & $108.5 \mathrm{~cm}$ & $125.7 \mathrm{~cm}$ & $122 \mathrm{~cm}$ & $118.7 \mathrm{~cm}$ \\
\hline $\mathbf{2 0 0 8}$ & $94.5 \mathrm{~cm}$ & $84.9 \mathrm{~cm}$ & $80.1 \mathrm{~cm}$ & $86.5 \mathrm{~cm}$ \\
\hline $\mathbf{2 0 0 9}$ & $89.9 \mathrm{~cm}$ & $83.7 \mathrm{~cm}$ & $91.6 \mathrm{~cm}$ & $91.6 \mathrm{~cm}$ \\
\hline $\mathbf{2 0 1 0} *$ & $80.2 \mathrm{~cm}$ & $72.2 \mathrm{~cm}$ & $76.1 \mathrm{~cm}$ & $76.2 \mathrm{~cm}$ \\
\hline
\end{tabular}

Notes: 2010 data through October. Includes early June rains at Frankfort station, which exceeded average by $16.2 \mathrm{~cm}$. Centralia station did not have data from 2007-2010, thus Goff station was used; a station south and east. Mean precipitation for the Black Vermillion area is $87.9 \mathrm{~cm}$ and a standard deviation of $20.4 \mathrm{~cm}$ period of record for average was 1970 through 2010.

Hydrographs in Northeast Kansas are considered flashy, as discharge rises higher, faster, and recedes more quickly than prior to Euro-American settlement. Flashiness is attributed to channelization of the streams themselves along with increased impervious and semiimpervious surfaces conveying more runoff directly to the stream. Figures 3 through 6 illustrate stream flow rates in cfs during the study years. In 2007, the wettest year of the study, three peaks over 10,000cfs occurred and were spread out. In 2008, an average year regarding precipitation totals, peak runoff never exceeded nor reached the 1.5-year recurrence interval of $4900 \mathrm{cfs}$. In 2010, the driest year, the 1.5-year recurrence interval was exceeded during the month of June, as expected due to the excess rainfall for the month. 
Figure 3. Daily peak max flow data for 2007 (USGS gage \# 06885500). The 1.5-yr recurrence interval discharge is approximately 4900cfs. January begins at 0 .

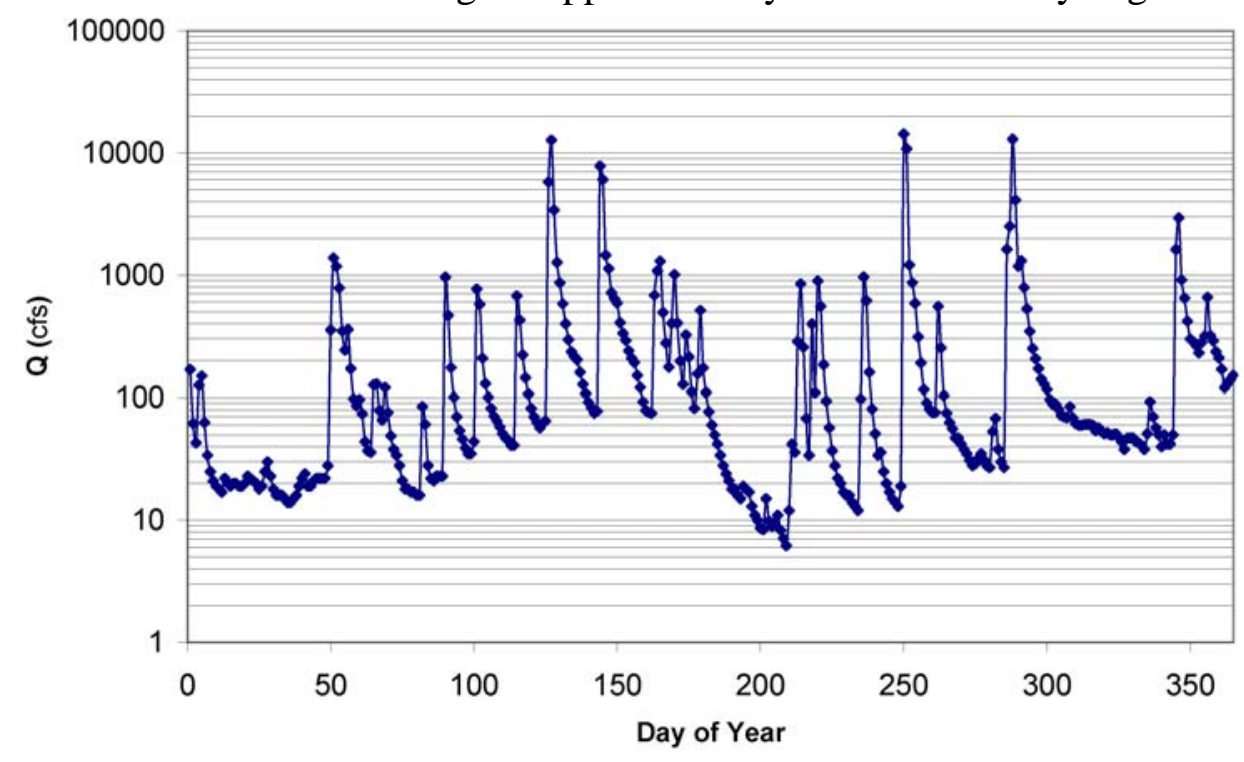

Figure 4. Daily peak max flow data for 2008 (USGS gage \# 06885500).

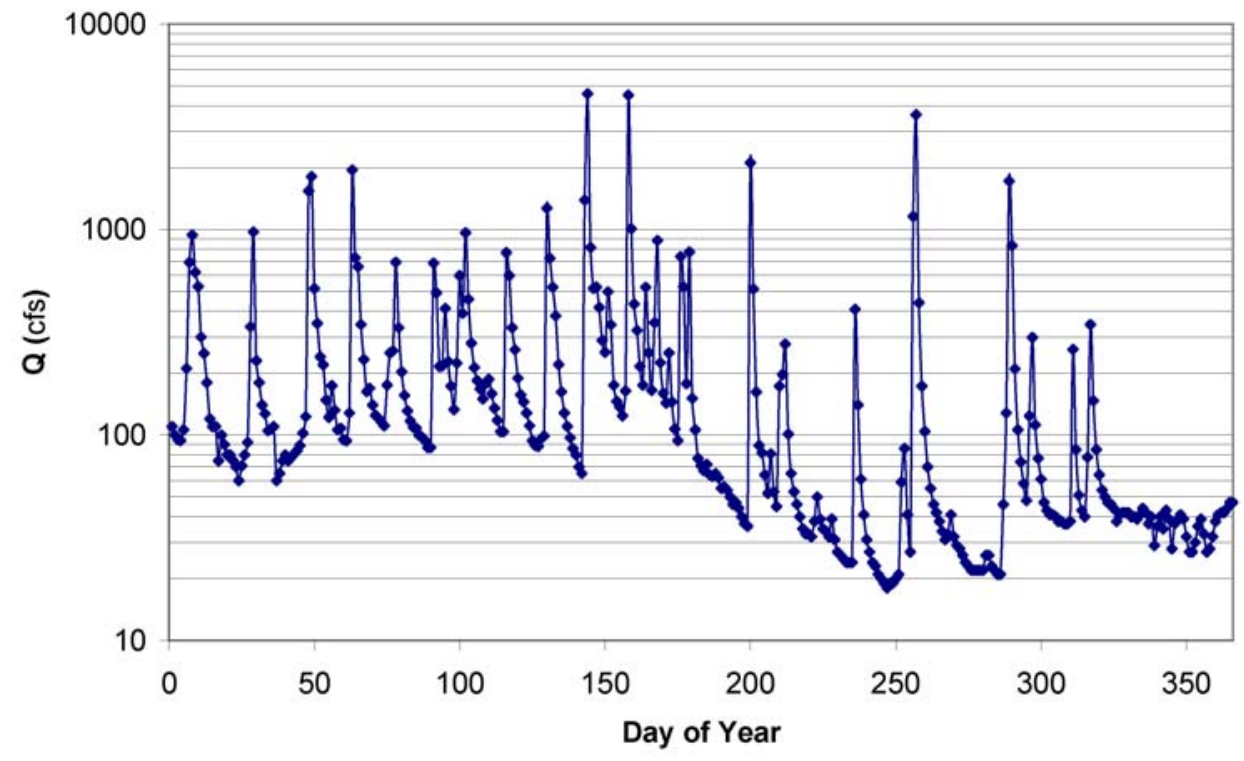


Figure 5. Daily peak max flow data for 2009 (USGS gage \# 06885500).

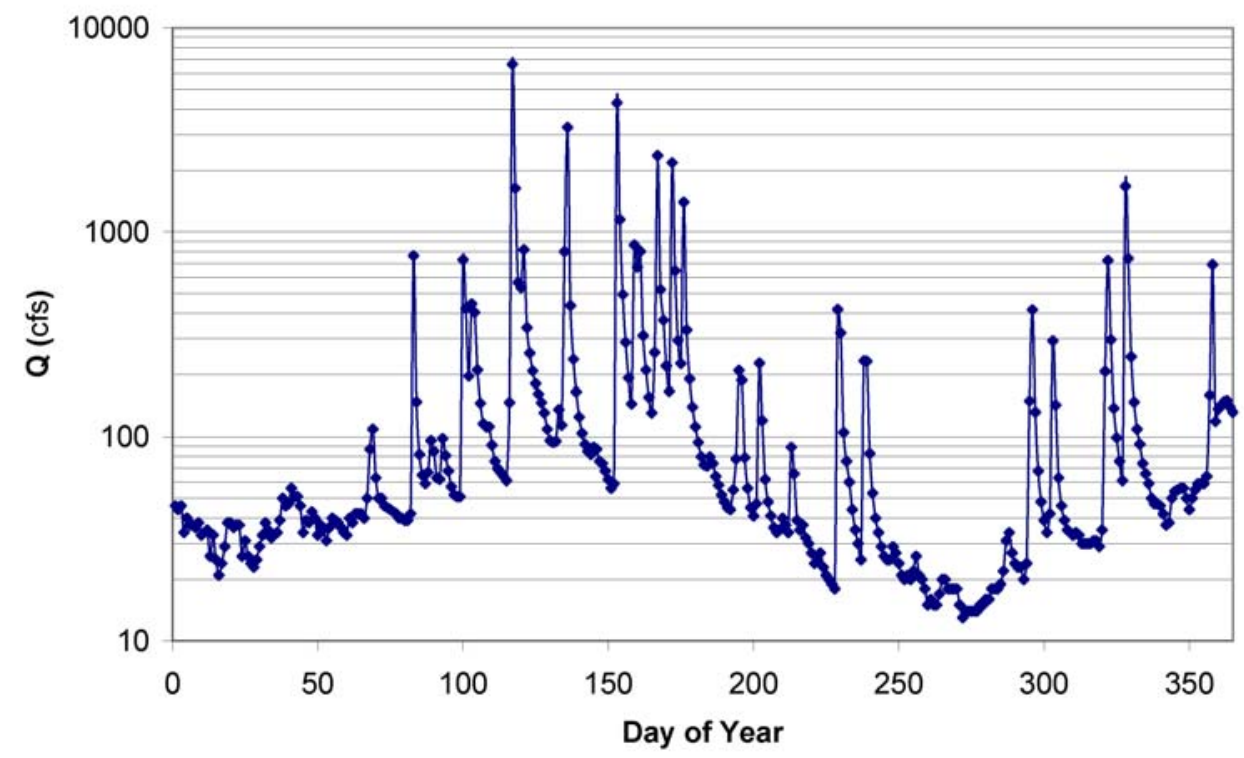

Figure 6. Daily peak max flow data for 2010 (USGS gage \# 06885500).

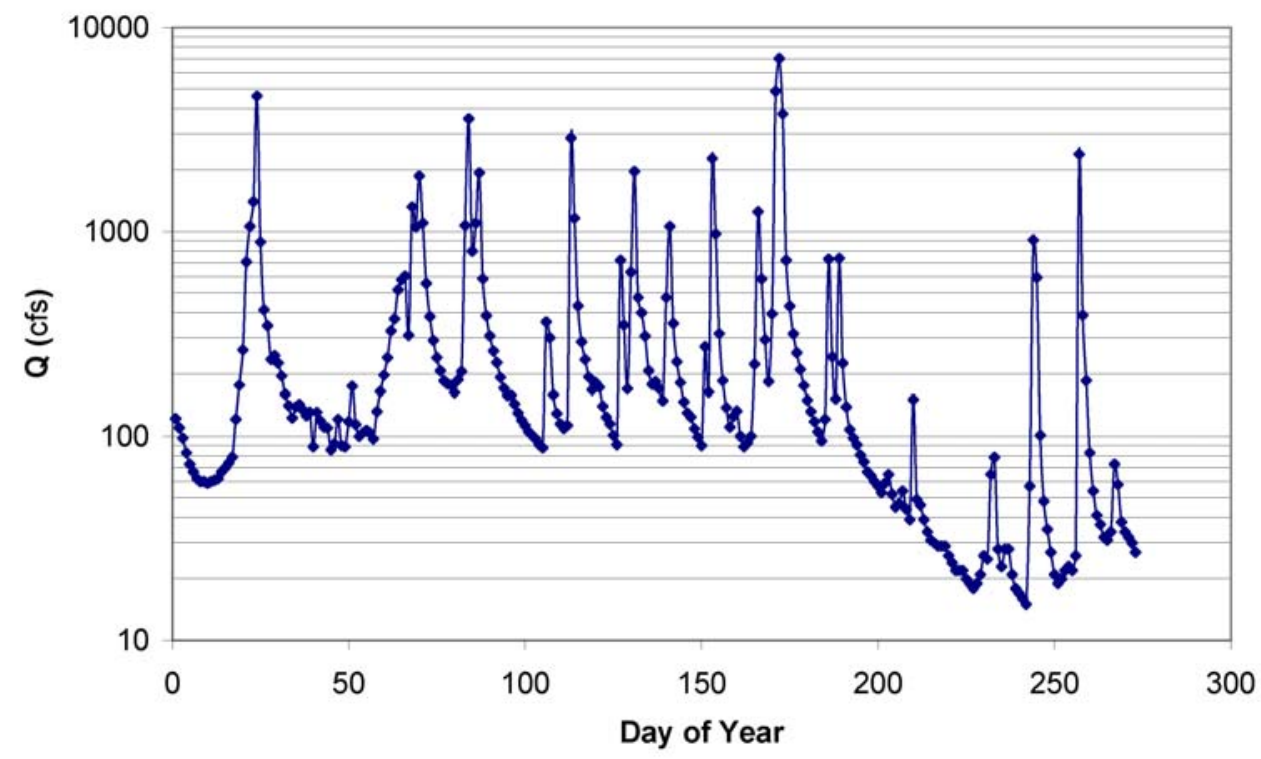

Riparian vegetation in the Black Vermillion watershed has been reduced significantly over the past 60-years with the building of many flow-through reservoir structures and significant channelization. The uplands of the basin are dominated by tillage/row crop agriculture and contain some native or introduced grass meadows and pastures (Table 3). In addition, approximately $64.4 \mathrm{~km}$ of $89.4 \mathrm{~km}$ of stream length lacks woody riparian corridor in this system.

Table 3. Approximate percentages (\%) of land cover by watershed (National Land Cover Data Set, 2001).

\begin{tabular}{|l|l|l|l|l|}
\hline & Cropland & Pasture & Woodland & Misc. \\
\hline IC & 65 & 30 & 2 & 3 \\
\hline
\end{tabular}




\begin{tabular}{|l|l|l|l|l|}
\hline NF & 79 & 15 & 2 & 4 \\
\hline BV & 75 & 20 & 2 & 3 \\
\hline
\end{tabular}

\section{Methods}

Rosgen (1996, 2006) methodology of stream classification and monitoring was utilized in this study. Four levels of assessment and monitoring are employed in the Rosgen system of classification and stream monitoring (Rosgen, 1996, 2006). Each level in this system becomes progressively more detailed. For example, Levels I and II describe reach characteristics and result in the typical letter and number nomenclature commonly cited for this system. Levels III and IV measure variables to assess the current state of the stream and then attempt prediction of future trends the stream may experience if all things remain constant. Examples of measures taken include longitudinal profiles of the stream reach, cross sections at stream facets, streambank profile measurements, scour chains, sediment characterization (modified Wolman pebble counts) and general velocity calculations (Rosgen, 1996). Rosgen (1996) Levels I through IV classification and assessment were completed for three years (2007 through 2009) on all nine sites during a larger geomorphic watershed study funded by the USDA-CSREES.

Specifically, the work reported here utilized bank profiling (field-measured erosion rates) and the Bank Assessment for Non-point Source Consequences of Sediment (BANCS) model to develop erosion prediction curves, a portion of Level IV assessment and prediction. Rosgen (2001, 2006) developed predictive erosion rating curves for both the Southern Colorado and Yellowstone regions using the BANCS model, more specifically Near Bank Stress (NBS) assessment and Bank Erosion Hazard Index (BEHI) assessment. Predictive erosion curves have been developed in other hydrophysiographic regions of the United States using similar methods: Northern Arkansas (Van Eps et al. 2004) and the Piedmont region of North Carolina (Jennings and Harman, 2001). All regions differ significantly from Northeast Kansas in terms of climate, vegetation, soils, and runoff. Our initial bank profiles were completed in 2007 with each being re-profiled annually through 2010. Two study banks were installed at each steam reach, one located at a pool crosssection and another on a representative bank of the reach. Each studied bank was evaluated and scored for BEHI and NBS following Rosgen's (2006) described methods.

\section{BEHI}

The Bank Erosion Hazard Index (BEHI) (Rosgen, 1996, 2001, 2006, 2008a, 2008b) is a process-integrated evaluation regarding the susceptibility of a bank to erosion utilizing known variables that affect bank erosion rates. BEHI considers several variables through visual assessments and measured ratios that indicate bank erosion susceptibility. Seven variables are assessed, scored on a basis of 1 to 10 (1 being low susceptibility and 10 being high), and added together to determine an overall BEHI score. Thus, all variables scored carry the same weight in the model. These numerical scores correlate to an adjective rating scale for that bank's susceptibility to erosion (very low 5-9.5, low 10 19.5, moderate 20-29.5, high 30-39.5, very high 40-45, extreme 46-70). Measured ratios and variables are as follows: 
1. Study bank height / bankfull height ratio (1-10 points)

Total bank height divided by bankfull height to compensate and adjust for stream size. The closer the ratio is to 1.0, the lower the risk of erosion of the bank.

2. Root depth / study bank height ratio (1-10 points)

Predominant rooting mass depth divided by total bank height calculates approximate cohesion of bank material by vegetation. If the root mass does not reach the bottom of the bank, undercutting of the bank material may occur causing the top of the bank to fail.

3. Weighted root density (percentage) (1-10 points)

Visual assessment of root density multiplied by root depth / study bank height ratio. The greater the weighted root density, the lower the risk of erosion.

4. Bank angle (degrees) (1-10 points)

The steeper the bank angle, the greater the risk of mass failure of the bank due to gravitational force and shear stresses.

5. Bank surface protection (1-10 points)

Measure of bank area as a percentage that is protected by sod mats, large woody debris, and revetments. The more protection, the lower the risk of erosion.

Adjustment categories (Bank Material and Stratification) aid in the consideration of additional erosion variables.

6. Bank material adjustment (-10 to10 points)

Different types of bank materials have different erosion rates, thus an adjustment to the BEHI score may be appropriate. For example, cohesive clay banks erode more slowly than sand banks. In this category, one can adjust for bank material erosion differential (within certain materials) by adding or subtracting up to 10 points from the BEHI score. Currently, there is no addition or subtraction for high clay soils.

7. Stratification of bank material (1-10 points)

Layers in the soil matrix can cause weak points on the bank face. If stratification exists specifically at the bankfull stage height, up to 10 points may be added to the total BEHI score to account for such stratification.

$\underline{\text { NBS }}$

Near Bank Stress (NBS) approximates erosional force of the outer $1 / 3$ of the water column acting on the eroding bank (cutbank) at bankfull stage flow (Rosgen, 1996, 2001, 2006, 2008a, 2008b). There are seven ways to assess near bank stress and they vary depending on the Rosgen Level (I-IV) of stream monitoring completed. These seven methods are not averaged, as the highest resultant adjective rating (very low, low, moderate, high, very high, extreme) of all calculated methods is recommended (Rosgen, 2006). Seven assessments to assign an adjective rating to NBS include:

1. Channel pattern, transverse bar or split channel / central bar creating NBS (Level I),

2. Ratio of radius of curvature to bankfull width (Level II), 
3. Ratio of pool slope to average water surface slope (Level II),

4. Ratio of pool slope to riffle slope (Level II),

5. Ratio of near-bank maximum depth to bankfull mean depth (Level III),

6. Ratio of near-bank shear stress to bankfull shear stress (Level III),

7. Velocity profiles / Isovels / Velocity gradients (Level IV).

Streambank Profiles

Streambank profiles were completed on an annual basis over a four-year period, 20072010, to assess erosion rates (Figure 7). Bank profiles were completed from the end of May through the end of July and then re-profiled approximately one year later (20072010). Bank pins were utilized as a measurement check and additional control points regarding erosion rates. Assessments of BEHI and NBS were completed during the initial bank profile, summer 2007. Table 4 illustrates the results of bank assessments and erosion rates calculated from area change of bank profiles from pool cross-section banks and study banks. The retreat (erosion) rate was calculated by dividing the cross-sectional area difference from each year by the height of the bank, which resulted in an average linear rate of erosion (example of bank difference from 2007 through 2009 can be seen in Figure 8). Bank measures were taken from the toe of the bank to the top of the low bank, which often is the top of the bank in entrenched channels. These banks ranged in height between $4.27 \mathrm{~m}$ to $6.73 \mathrm{~m}$ while expected bankfull stage was often less than $1.5 \mathrm{~m}$ from the bottom of the channel at a riffle. Different portions of the bank may erode at a faster rate than other portions of the bank. However, the predictive capacity of the model should yield an average rate of bank retreat.

Figure 7. Bank profile example and measures. Toe pin is used as a control point at the bottom of the bank; vertical and horizontal distances are taken from toe pin to face of bank (authors).

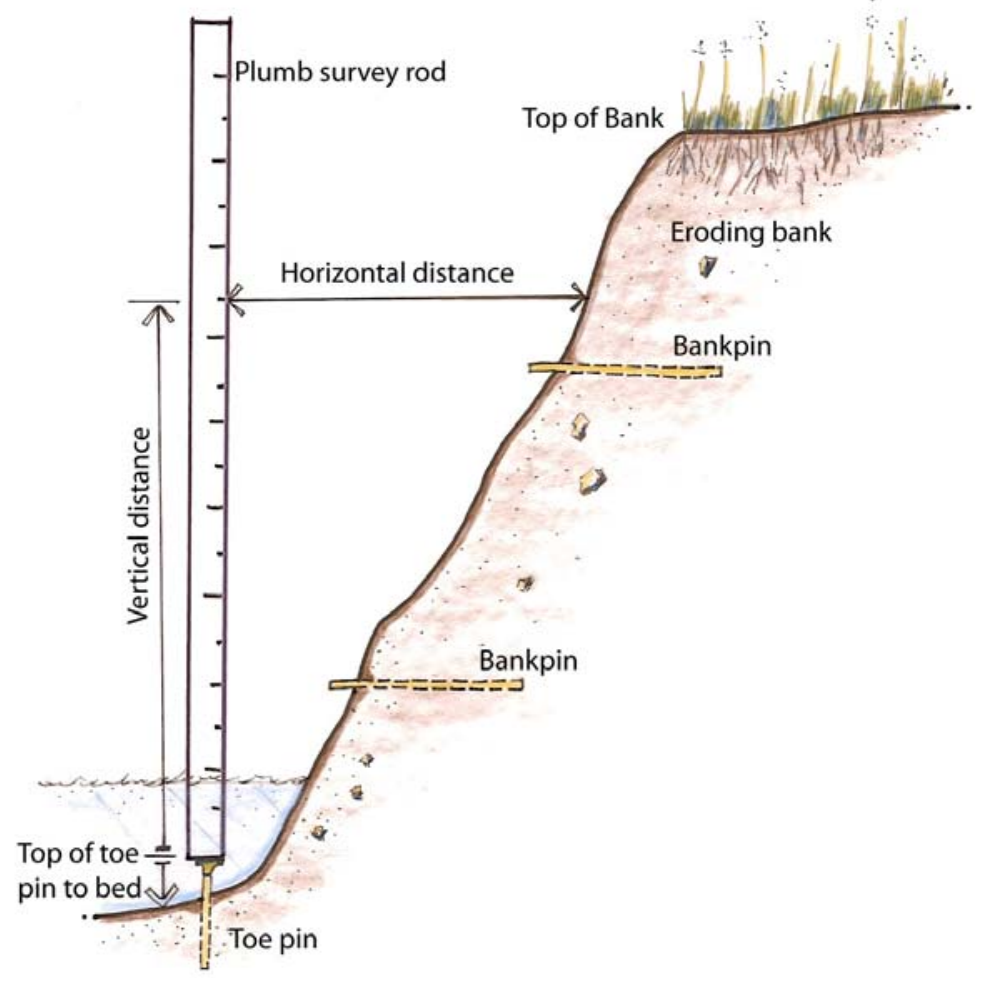


Figure 8. Bank profile overlay example for erosion measures. This particular bank is located at North Fork reach 1 at the pool cross section.

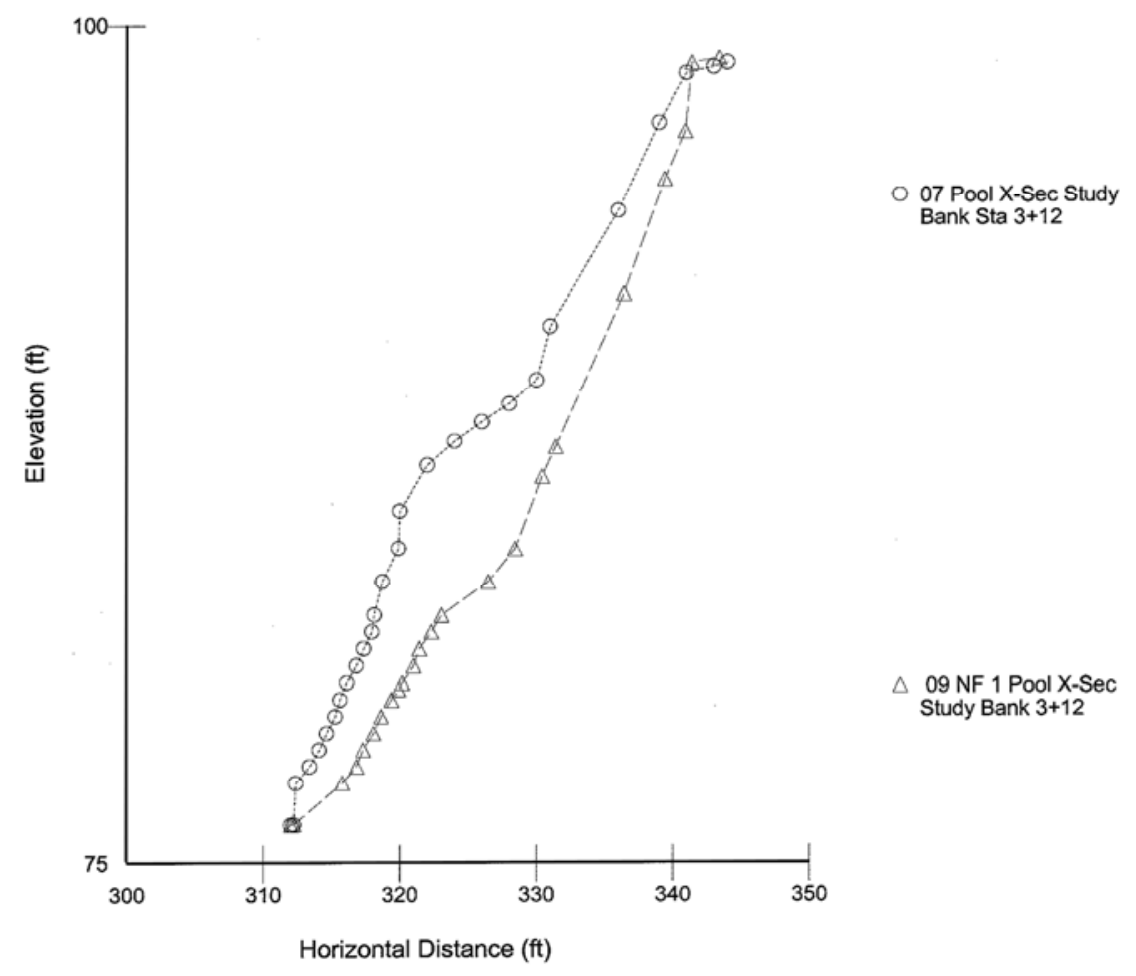

Average erosion rates were based upon measured field data and calculated to best fit the conditions of the studied bank. Two banks, Main Stem 2 and Main Stem 3, experienced bank slump with toe pins being buried by mass movement of the bank material toward the stream. These two banks actually aggraded or filled as opposed to eroding, therefore they were not calculated in the average for the entire study period; only the 2007-2008 change was used. Since these stream reaches are in incised channels that have been straightened, it becomes difficult to ascertain which bank is actively eroding. Two banks in particular exhibited only deposition instead of erosion; Main Stem 3-study bank and Irish Creek 2-pool. All rates exhibiting deposition were disregarded because this study sought to measure erosion rates in Northeast Kansas, not overall channel change.

In addition, two study bank erosion rates for 2009-2010 were assumed, as each bank's toe pin and erosion pins were lost due to mass failure of that bank. At North Fork 3 study bank location, all three $1.22 \mathrm{~m}$ bank pins were found downstream while no toe pin was found at the bank site; thus $1.22 \mathrm{~m}$ of erosion was assumed. This site was located downstream of an outside bend of convergent stream channels creating high bank stresses. At the Irish Creek 2 study bank site, all bank pins were again lost. However, a bench of failed material covered the toe pin approximately one to $1.25 \mathrm{~m}$ in depth, which was approximately one-third of the total bank height. Only $0.9 \mathrm{~m}$ of erosion was assumed due to the subsequent deposition at the bank toe of failed bank material and estimated total toe pin area change (Figure 9). This site was located on the downstream side of a transverse bar creating higher bank stresses. 
Streams in the watershed are low gradient $(<.01)$, typically entrenched, straightened through channelization, and have high vertical banks. These characteristics are evidenced through the Rosgen stream types found in this watershed. In addition, these stream types typically experience high bank erosion rates and thus exhibit high lateral instability. Most stream reaches were experiencing bed aggradation that also increases bank erosion rates (Rosgen, 1996, 2006).

Table 4. Pool bank and study bank profile erosion rates calculated from crosssectional area changes between 2007-2010. Negative (-) numbers indicate net deposition, or loss of cross-sectional area.

\begin{tabular}{|c|c|c|c|c|c|c|c|}
\hline & $\begin{array}{l}\text { Rosgen } \\
\text { Stream } \\
\text { Type }\end{array}$ & $\begin{array}{l}\text { BEHI-NBS } \\
\text { Combination }\end{array}$ & $\begin{array}{l}07-08 \\
\text { (m) }\end{array}$ & $\begin{array}{l}\text { 08-09 } \\
(\mathrm{m})\end{array}$ & $\begin{array}{l}09-10 \\
\text { (m) }\end{array}$ & $\begin{array}{l}\text { Average } \\
\text { retreat/yr } \\
\text { (m) }\end{array}$ & $\begin{array}{l}\text { Average } \\
\text { bank height } \\
\text { (m) }\end{array}$ \\
\hline Main Stem 1p & G5c & Moderate/Moderate & 0.39 & 0.20 & -0.12 & 0.29 & 4.27 \\
\hline Main Stem 1s & G5c & High/V. Low & 0.39 & 0.11 & 0.05 & 0.18 & 4.27 \\
\hline Main Stem 2p & G5c & High/V. Low & 0.10 & -0.61 & Slump & 0.10 & 4.60 \\
\hline Main Stem 2s & G5c & V. High/Moderate & 0.41 & -0.07 & 0.77 & 0.57 & 4.60 \\
\hline Main Stem 3p & F5 & High/Low & 0.14 & -0.07 & Slump & 0.14 & 5.73 \\
\hline Main Stem 3s & F5 & High/Moderate & -0.10 & -0.10 & Slump & -0.10 & 5.73 \\
\hline North Fork 1p & G5c & High/ V. High & 1.11 & 0.36 & $\mathrm{n} / \mathrm{m}$ & .73 & 6.31 \\
\hline North Fork 1s & G5c & High/High & Reset & 0.24 & 0.20 & 0.22 & 6.31 \\
\hline North Fork 2p & G5c & High/V. High & 1.28 & 0.27 & -0.19 & 0.77 & 4.94 \\
\hline North Fork 2s & G5c & Moderate/Moderate & 0.23 & Reset & 0.40 & 0.32 & 4.94 \\
\hline North Fork 3p & G5c & Moderate/Moderate & 0.49 & 0.28 & 0.40 & 0.39 & 4.91 \\
\hline North Fork 3s & G5c & High/Extreme & 0.71 & 0.73 & 1.22 & 0.89 & 4.91 \\
\hline Irish Creek 1p & G4c & V. High/Low & 0.14 & 0.16 & 0.30 & 0.20 & 5.15 \\
\hline Irish Creek 1s & G4c & Moderate/V. Low & 0.06 & 0.11 & $\mathrm{n} / \mathrm{m}$ & 0.09 & 5.15 \\
\hline Irish Creek 2p & G4c & Moderate/ Moderate & -0.27 & -0.10 & $\mathrm{n} / \mathrm{m}$ & -0.19 & 6.73 \\
\hline Irish Creek 2s & G4c & High/Moderate & 0.28 & 0.39 & 0.91 & 0.53 & 6.73 \\
\hline
\end{tabular}




\begin{tabular}{|l|c|c|c|c|c|c|c|}
\hline Irish Creek 3p & B5c & High/Moderate & 0.16 & 0.13 & 0.40 & 0.23 & 5.24 \\
\hline Irish Creek 3s & B5c & High/Low & 0.07 & 0.11 & 0.19 & 0.12 & 5.24 \\
\hline
\end{tabular}

Note: "p" indicates pool study bank; "s" indicates study bank; "n/m" = not measured that year due to little or no change according to bank pins; "Slump" indicates toe pin was lost due to aggradation; "Reset" indicates the bank toe pin was lost and then reset at the appropriate longitudinal profile station.

Figure 9. Irish Creek 2 Study Bank example illustrating loss of bank pins and toe pin. Bank slumped and left approximately one-third of the bank height at the bank toe; thus only $0.91 \mathrm{~m}$ of retreat was assumed. The accompanying drawing illustrates the assumption of how the bank failed.

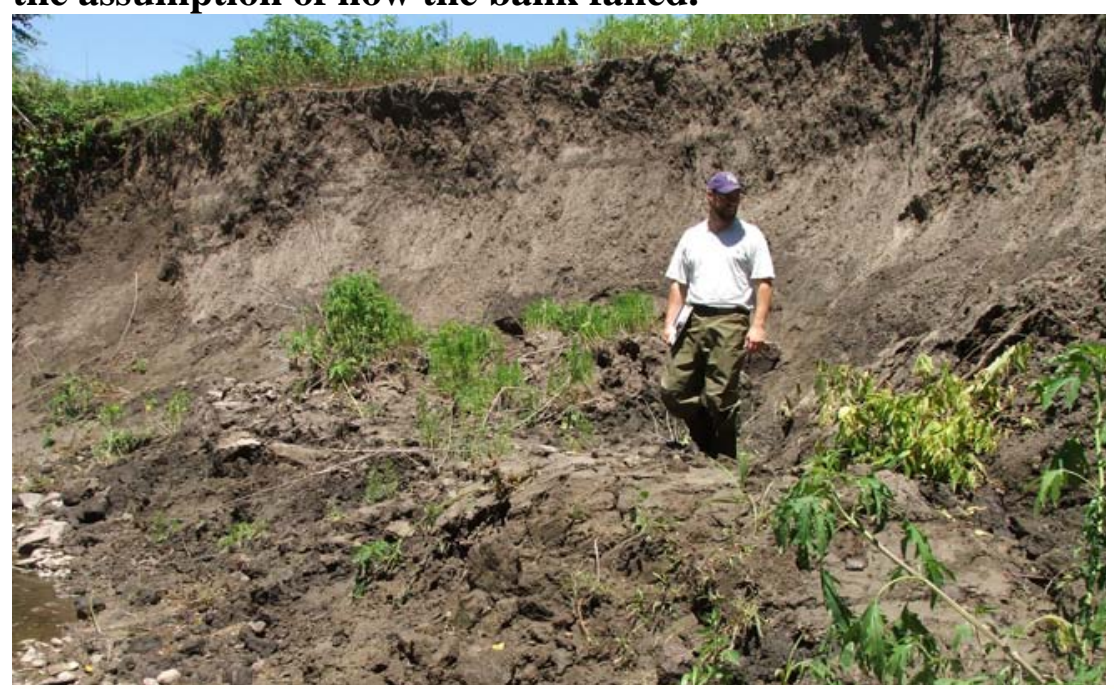

Cross-section Pre-failure

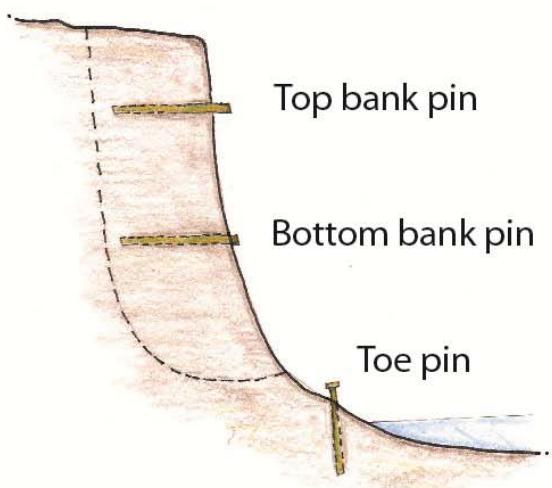

Typical bank profile
Cross-section Post-failure

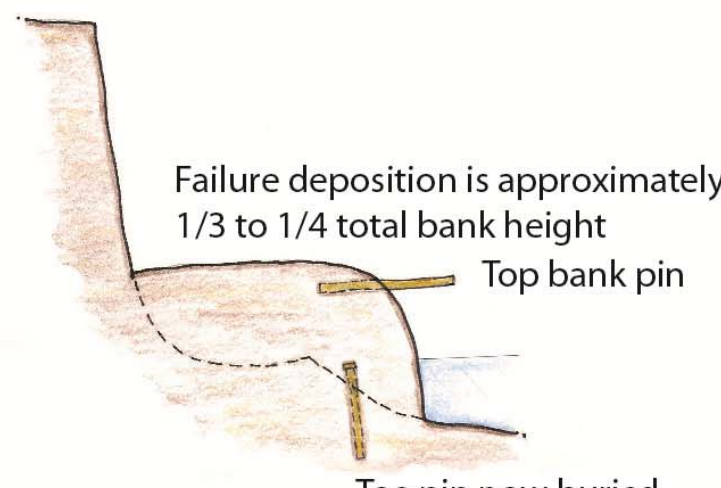

Toe pin now buried

\section{Results and Discussion}

The BANCS model developed by Rosgen (1996, 2001, 2006, 2008a, 2008b) was used to synthesize BEHI, NBS and measured erosion rate data. Figure 10 illustrates the results of this synthesis where NBS is plotted along the $\mathrm{X}$-axis, erosion rate is plotted along the $\mathrm{Y}$ axis and each trend line is a BEHI rating. This study did not include very low, low or extreme BEHI ratings as conditions meriting those hazard ratings were not present in our 
study reaches. Table 5 compares predicted erosion rates in meters of bank retreat per year from the different erosion prediction curves developed around the country. Four different rating combinations were used as comparison. Note the North Carolina Piedmont curves were developed differently in that Jennings and Harmon (2001) used a best fit line for all sites with BEHI scores along the X-axis. In contrast, Northeast Kansas field sites were monitored for three years while field sites in the other four studies were monitored one year.

Figure 10. BEHI - NBS erosion prediction curves developed using average erosion rates over four-year study period with Black Vermillion data in Northeast Kansas. Moderate BEHI (Blue) $\mathbf{R}^{2} 0.75$ (4 data points) while High BEHI (Magenta) $\mathbf{R}^{2} 0.77$ (12 data points).

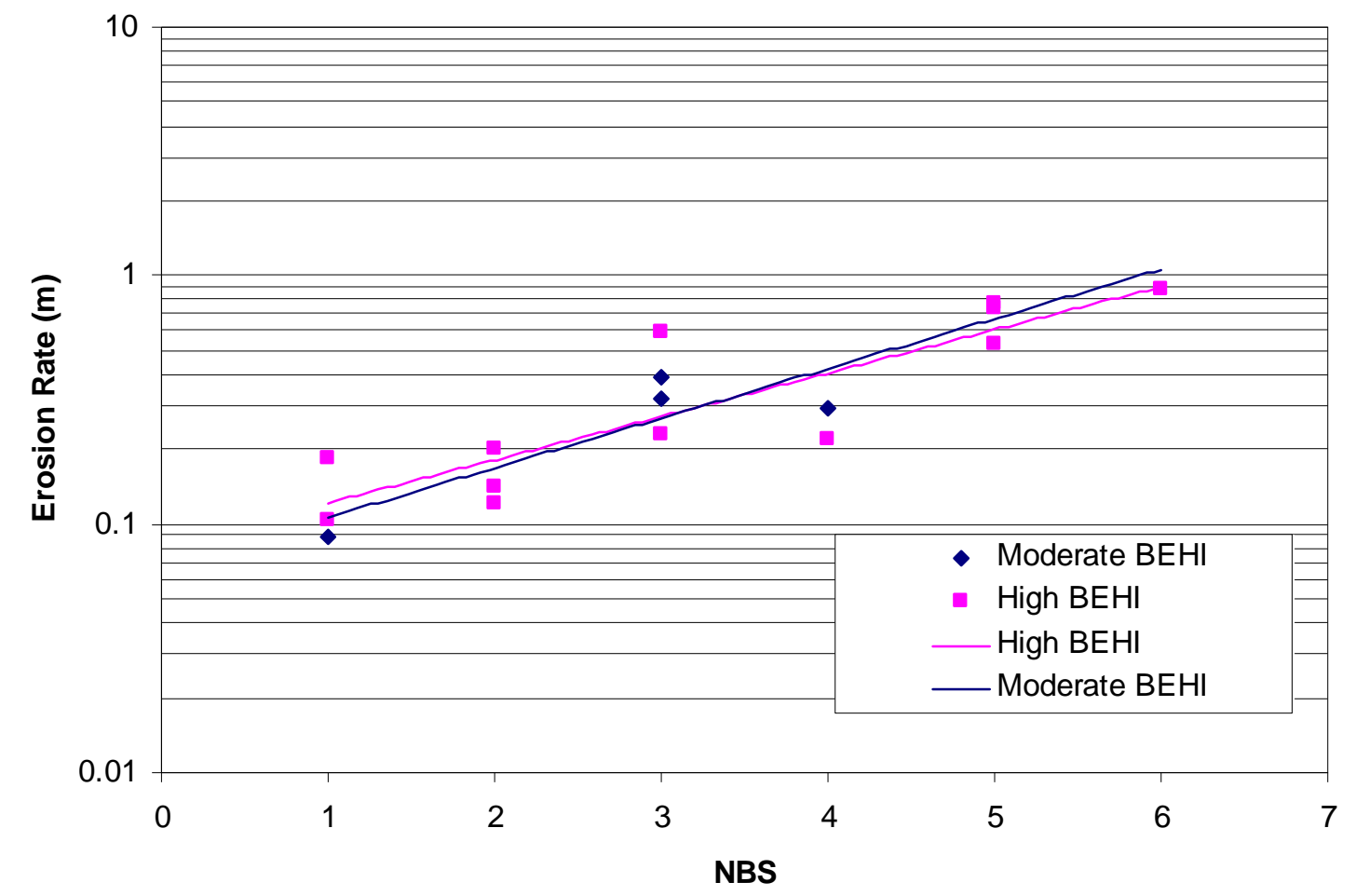

Table 5. Comparison table illustrating erosion differences between different curves developed across the country (shown in meters of predicted bank retreat per year).

\begin{tabular}{|l|c|c|c|c|c|}
\hline $\begin{array}{l}\text { BEHI-NBS } \\
\text { Rating }\end{array}$ & Colorado & Yellowstone & North Carolina & Arkansas & NE Kansas \\
\hline Moderate/Low & 0.05 & 0.05 & 0.03 & 0.02 & 0.17 \\
\hline Moderate/High & 0.13 & 0.15 & 0.03 & 0.05 & 0.43 \\
\hline High/Low & 0.08 & 0.16 & 0.08 & 0.05 & 0.19 \\
\hline High/High & 0.17 & 0.34 & 0.08 & 0.12 & 0.40 \\
\hline
\end{tabular}

Note: These are all predictions from each respective curve developed from measured data. Erosion rates predicted using High/Low in NE Kansas curves predict less erosion than that predicted by Moderate/High NE Kansas curves. 
Figure 10 and Table 5 suggest some component(s) of the BANCS model as described by Rosgen $(2001,2006)$ may not fit our set of conditions in Northeast Kansas.

Inconsistencies include the High/Very High BEHI rating curve trend line predicting lower erosion rates than the Moderate BEHI, while the opposite should be true. In addition, trend line slopes should not intersect, as they do at lower NBS ratings (approximately 2.5). Discrepancies such as these indicate an erosion variable or process may not be accounted for, or may be over or under represented, using the BEHI portion of the BANCS model in Northeast Kansas. Since NBS is an approximation of shear stresses, it should approximate similar stress conditions in all systems equally, thus it was not considered for modification in this study. BEHI, which is used as an assessment of bank erosion resistance, may require modification for differing erosional processes and controls in Northeast Kansas.

Modification of an existing model, specifically the BEHI portion of the BANCS model, seems warranted because the model has proven to work in other regions of the United States (Van Eps et al, 2004; Jennings \& Harmon, 2001; Rosgen, 1996). The BEHI assessment utilizes a process integrated approach where erosional processes are combined and assumed to contribute equally to overall erosion which is calculated using ratios or variables that typically indicate susceptibility to erosion. However, there may be one or two processes, or variable attributes, contributing a majority of erosional work in Northeast Kansas. Isolation of the dominant processes or contributing attributes in Northeast Kansas should enable the modification of the BEHI assessment to account for those processes or attributes while continuing to utilize this established model.

Literature suggests woody vegetation lessens erosion rates through energy dissipation of the water column. This is accomplished by increasing roughness and tensile strength resulting in increased cohesion provided by the root-soil matrix (Schumm, 1973; Thorne, 1990; Gurnell, 1997; Genet et al. 2005; Pollen, 2007). In addition, it has been shown that different species of vegetation provide varied amounts of tensile strength to soils (Genet et al. 2005; Pollen, 2007). Vegetation also influences each of the three bank erosion processes as described by Lawler (1995): subaerial processes and erosion, fluvial entrainment, and mass failure through modification of the local microclimate, alteration of soil moisture, and reinforcement of the bank material against hydraulic and mechanical shear stresses respectively (Wynn \& Mostaghimi, 2006). Wynn and Mostaghimi (2006) found root density to have a significant impact on bank erosion in Southwestern Virginia. In this light, additional analysis was conducted to test vegetative influences on erosion in this region.

An additional variable considered during this study is soil material properties. Wynn and Mostaghimi (2006) found that bulk density of soils was the most significant factor affecting bank erosion, where the higher bulk density soils resulted in decreases in soil erodibility. Soils rich in clays typically have high bulk density, which is the case in Northeast Kansas and more specifically the Black Vermillion watershed (Table 2). In addition, clays tend to hold together much better than other soil particle sizes while the threshold of failure is much higher in clays (Schumm, 1973). As noted by Wynn and Mostaghimi (2006), Grissinger (1982) states that "Soils with low interparticle distances 
(high bulk density) are less susceptible to swelling and erosion upon wetting (p78)." The soils in the Wynn and Mostaghimi (2006) study were much lower in clay content (2 11\%) than estimated clay content in this study (23 - 47\%) (USDA, 2011). It is expected that additional analysis of the bank material soils will exhibit high clay content which likely affect bank erosion processes and rates in the Black Vermillion watershed significantly.

\section{Woody Riparian Vegetation and Bank Erosion Rates}

Each of our study banks was grouped according to influential amounts of riparian vegetation on and above the assessed bank. Three groups of vegetation amounts and types were informed from the 18 bank locations. These included: no vegetation (1), little vegetation (2), and ample vegetation (3) (Figure 11). No vegetation included those banks influenced by tillage agriculture, brome pasture and shallow-rooted herbaceous plants only. Little vegetation included some woody vegetation, corridor widths usually less than two rows of trees with little age or species diversity. Willow thicket influence was also included in this category. Ample vegetation included those areas with strong influences from surrounding large riparian vegetation. This grouping exceeded two rows of woody vegetation and included diverse age and species composition in the riparian corridor. These woody vegetation groupings were plotted against BEHI and NBS scores with corresponding erosion rates.

Figure 11. Woody vegetation amount types and scores for BEHI modification. Cross-sectional view

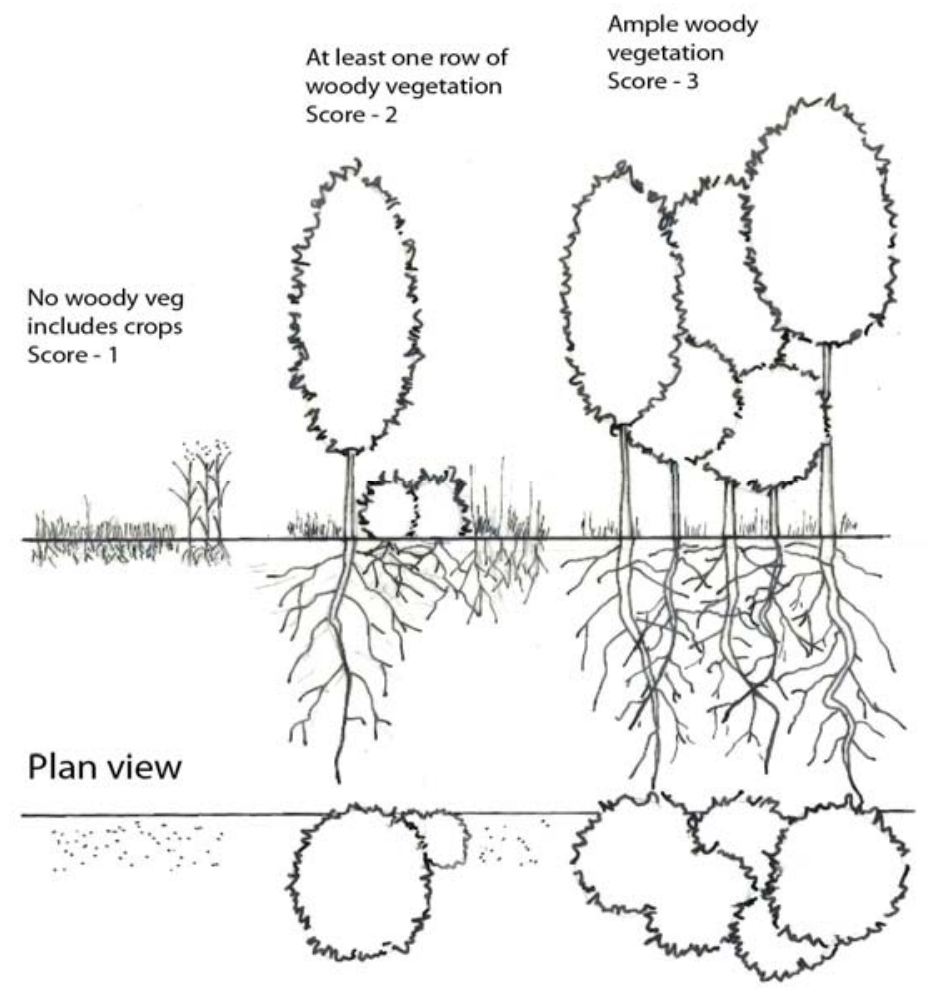




\section{BEHI-NBS Score and Woody Vegetation Erosion Rates}

Bank Erosion Hazard Index (BEHI) and Near Bank Stress (NBS) scores and ratings were plotted versus erosion rates and further separated by amount of riparian woody vegetation present at the study bank site. The eighteen study banks were assessed for woody vegetation in 2007 and again in 2010 (no change to the vegetation amounts or types). The woody vegetation results by location can be found in Table 6, while the plotted results of BEHI score versus erosion rates (by amount of vegetation) can be found in Figure 12. NBS was also plotted versus erosion rate and vegetation amounts and performed as expected. Higher NBS ratings produced higher erosion rates. Although, those sites having similar NBS ratings exhibited higher erosion rates without vegetation than with.

Table 6. Location and amount of Woody Vegetation at bank sites; categories for vegetation influence (1) no vegetation, (2) little vegetation, and (3) ample vegetation (Figure 11).

\begin{tabular}{|l|l|l|l|}
\hline Location & $\begin{array}{l}\text { Woody } \\
\text { Vegetation }\end{array}$ & Location & $\begin{array}{l}\text { Woody } \\
\text { Vegetation }\end{array}$ \\
\hline MS1p & No (1) & MS1s & No (1) \\
\hline MS2p & Yes (3) & MS2s & Yes (3) \\
\hline MS3p & Yes (3) & MS3s & Yes (3) \\
\hline NF1p & No (1) & NF1s & Yes (2) \\
\hline NF2p & No (1) & NF2s & No (1) \\
\hline NF3p & No (1) & NF3s & No (1) \\
\hline IC1p & Yes (3) & IC1s & Yes (3) \\
\hline IC2p & Yes (2) & IC2s & No (1) \\
\hline IC3p & Yes (2) & IC3s & Yes (2) \\
\hline
\end{tabular}

Figure 12 illustrates higher erosion rates occur where no vegetation exists. In contrast, where at least some vegetation exists erosion rates are much less. The BEHI model developed by Rosgen (2001, 2006) incorporates two vegetation components; however, looking at the BANCS model results, the BEHI model may not evaluate vegetation that coincides with conditions in the Northeast Kansas region. As expected, the NBS model developed by Rosgen (2001, 2006) does seem to work in this region. Banks having lower NBS ratings, regardless of the woody vegetation influence, produce lower erosion rates than banks with higher NBS ratings. In addition, banks with vegetation with the same NBS ratings erode approximately half the rate than banks without woody vegetation. 
Figure 12. Plot of BEHI scores versus Erosion rates with corresponding woody vegetation amounts. Plot illustrates low BEHI scores with high erosion rates on banks without vegetation.

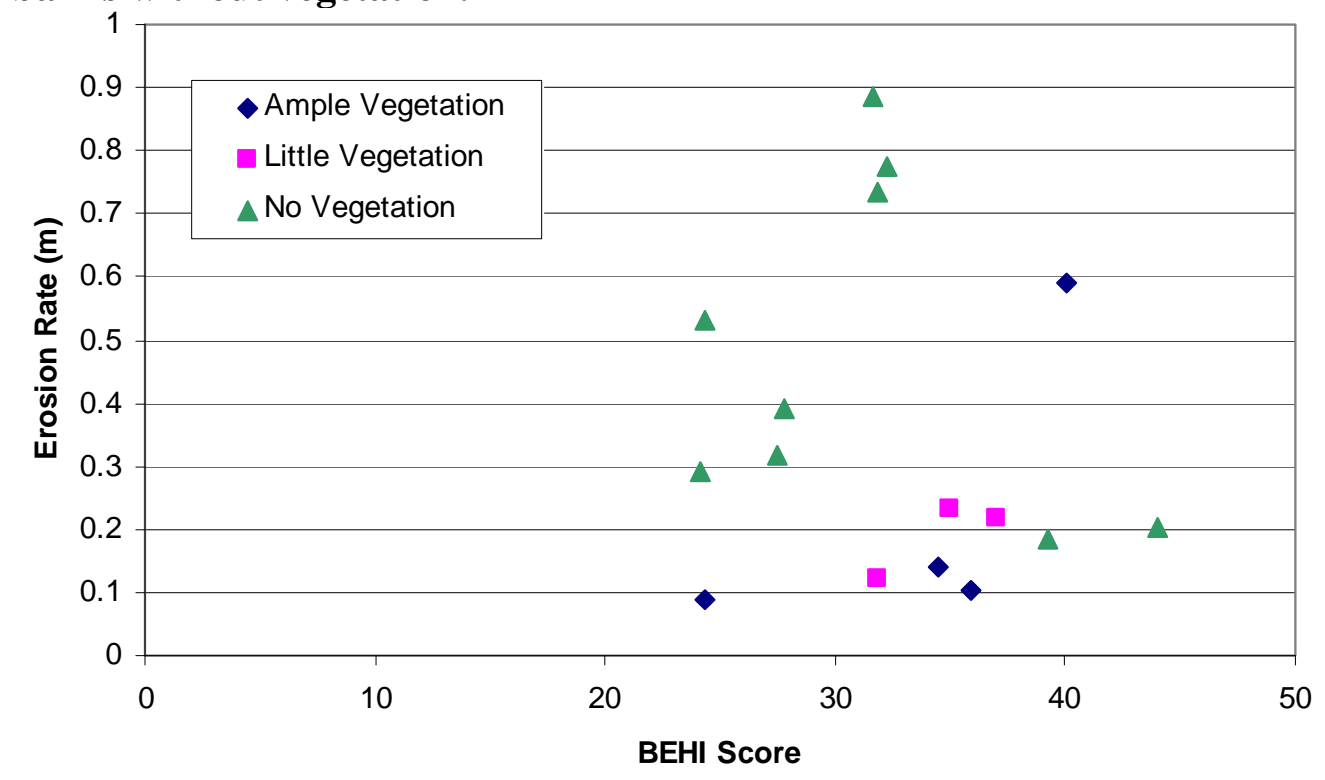

\section{Statistical Analysis of Vegetation}

Difference of means was calculated between the erosion rate means of banks with woody vegetation and banks without woody vegetation. A normal population of bank erosion rate was assumed and sample variance was calculated under this assumption. The mean rate of erosion on banks with woody vegetation was $0.18 \mathrm{~m}$, while a mean rate of erosion on a bank without woody vegetation was $0.48 \mathrm{~m}$. The test statistic used was a standardized $z$-test with an alpha of 0.05 . The resultant $z$-score of -2.96 indicated a significant statistical difference between the woody vegetation influenced banks versus non-vegetated banks' means analyzed. This significant difference between the means suggests vegetation may play a larger role in bank stabilization, or lack of stabilization, than the BEHI model accounts for in our region (Northeast Kansas).

\section{Vegetation modifications to BEHI assessment}

Modification to the vegetation assessment sections of BEHI is suggested in light of vegetation scores consistently creating a median score in this study. Both rooting depth ratio and weighted root density variables relate to similar processes and when combined produce a median score in our region. For example, vegetation in this region may have a deep rooting structure attaining a low BEHI score of 2-3 for the rooting depth category. However, root density is typically less than $30 \%$ attaining a High BEHI score of 8-9 for the weighted root density category. Thus, we combined the two categories into one creating a new category, Woody Vegetation Present. Scoring for this new category is calculated based upon woody vegetation present at the study bank. The bank scored a "low" erosion/BEHI rating and a numerical score of 2.5 if woody vegetation was present. If no woody vegetation was present, the bank scored a "high" rating and a numerical score of 8.5. This protocol is similar to Rosgen's BEHI scoring for Bank Material Adjustment when large boulders or bedrock is the bank material. Banks having large 
boulders or bedrock receive a Low or Very Low BEHI automatically. However, vegetation presence does not override all other BEHI scores like the adjustment for large boulders and bedrock. Figure 12 illustrates banks without vegetation erode roughly 3times more than banks with vegetation $(0.48 \mathrm{~m}$ erosion/yr without; $0.18 \mathrm{~m}$ erosion/yr with woody vegetation), thus 8.5 is approximately 3-times higher than the low average score of 2.5 .

Combining the BEHI categories of Root depth: Study bank height ratio and Weighted root density ratings into one category allows us to assess combined vegetation effects on erosional processes. While weight on the bank material is increased by the extra weight of vegetation itself, the increased bank shear strength and bank protection must prevail over the extra weight created by vegetation and water, as exemplified by the standardized z-test between the mean erosion rates of banks with and without woody vegetation. If this is the case, then vegetation affects erosion rates in this region at sites without a large percentage of root density holding the bank together. Root density in Northeast Kansas rarely exceeds 30\%; however, the soil-root matrix created provides extra tensile strength that is needed in clay-rich soils. Combining root density and root depth into one category allows us to score vegetation as high or low, and in doing so, we account for our lower root densities compared to those root densities where the BEHI model was developed. Once woody vegetation influences were scored, new overall BEHI ratings were attained and new predictive erosion curves developed.

\section{New BEHI Scores and Explanation}

Modifications developed in this study meant 11.5 less total points were possible in the total BEHI score (original BEHI developed by Rosgen total score possible 70, modified by Sass and Keane total score possible 58.5). Table 7 illustrates overall score comparison between the original BEHI model and the modified model. The adjective ratings associated with the modified BEHI scores are: 5.5-9 total points equates to Very Low, 9.5-19 total points equates to Low, 19.5-27 total points equates to Moderate, 27.5-45 total points equates to High-Very High (combined), 45.5-58.5 total points equates to Extreme (Rosgen, 2006). High and Very High adjective ratings were combined as they were in the original curves developed in Colorado and Yellowstone (Rosgen, 2001, 2006). Extreme ratings can only occur with the vegetation modification of BEHI if stratification or bank material adjustment additions are required. Table 7 illustrates a comparison between Rosgen scoring for the BEHI model versus our modifications for Northeast Kansas. Table 8 illustrates the new BEHI scores and associated ratings with each bank in the Black Vermillion watershed as converted from Figure 11. 
Table 7. Comparison between Rosgen BEHI and Northeast Kansas modifications scores per category. Different scoring systems are bolded.

\begin{tabular}{|l|c|c|}
\hline Category & Rosgen & NE Kansas \\
\hline Study Bank Height : Bkf Height & 1 to 10 & 1 to 10 \\
\hline Root Depth : Study Bank Height & $\mathbf{1}$ to $\mathbf{1 0}$ & N/A \\
\hline Weighted Root Density & $\mathbf{1}$ to $\mathbf{1 0}$ & N/A \\
\hline Woody Vegetation Present & N/A & $\mathbf{2 . 5}$ or $\mathbf{8 . 5}$ \\
\hline Bank Angle & 1 to 10 & 1 to 10 \\
\hline Surface Protection & 1 to 10 & 1 to 10 \\
\hline Bank Material Adjustment & -10 to 10 & -10 to 10 \\
\hline Stratification Adjustment & 1 to 10 & 1 to 10 \\
\hline Total Score Possible & $\mathbf{7 0}$ & $\mathbf{5 8 . 5}$ \\
\hline
\end{tabular}

Table 8. New adjusted BEHI scores with vegetation modifications to BEHI model.

\begin{tabular}{|l|c|c|c|c|c|c|c|c|c|c|}
\hline Bank Location & $\begin{array}{c}\text { SBH: } \\
\text { BkfH }\end{array}$ & WV & BA & SP & BMA & SA & $\begin{array}{c}\text { Overall } \\
\text { New } \\
\text { Score }\end{array}$ & $\begin{array}{c}\text { New } \\
\text { Rating }\end{array}$ & $\begin{array}{c}\text { Old } \\
\text { BEHI } \\
\text { Score }\end{array}$ & $\begin{array}{c}\text { Old } \\
\text { Rating }\end{array}$ \\
\hline Main Stem 1p & 8.5 & 8.5 & 3 & 2 & 0 & 0 & 22 & Moderate & 24 & Moderate \\
\hline Main Stem 1s & 8.5 & 8.5 & 4 & 6.5 & 0 & 0 & 27.5 & High & 39 & High \\
\hline Main Stem 2p & 8 & 2.5 & 2.5 & 10 & 0 & 0 & 23 & Moderate & 36 & High \\
\hline Main Stem 2s & 8 & 8.5 & 3 & 10 & 0 & 5 & 34.5 & High & 40 & V. High \\
\hline Main Stem 3p & 10 & 2.5 & 3 & 5 & 0 & 5 & 25.5 & Moderate & 34.5 & High \\
\hline Main Stem 3s & 10 & 2.5 & 3 & 5 & 0 & 5 & 25.5 & Moderate & 34.5 & High \\
\hline North Fork 1p & 10 & 8.5 & 3 & 10 & 0 & 0 & 31.5 & High & 32 & High \\
\hline North Fork 1s & 8.5 & 2.5 & 4 & 10 & 0 & 0 & 25 & Moderate & 37 & High \\
\hline North Fork 2p & 9 & 8.5 & 4 & 10 & 0 & 0 & 31.5 & High & 32.5 & High \\
\hline North Fork 2s & 8.5 & 8.5 & 3.5 & 10 & 0 & 0 & 30.5 & High & 27.5 & Moderate \\
\hline North Fork 3p & 8.5 & 8.5 & 3.5 & 10 & 0 & 0 & 30.5 & High & 28 & Moderate \\
\hline North Fork 3s & 8 & 8.5 & 3.5 & 10 & 0 & 0 & 30 & High & 26.5 & High \\
\hline Irish Creek 1p & 10 & 2.5 & 3.5 & 10 & 0 & 5 & 31 & High & 44 & Very High \\
\hline Irish Creek 1s & 10 & 2.5 & 1 & 1 & 0 & 0 & 14.5 & Low & 24.5 & Moderate \\
\hline Irish Creek 2p & 10 & 2.5 & 2.5 & 2 & 0 & 0 & 17 & Low & 20 & Moderate \\
\hline
\end{tabular}




\begin{tabular}{|l|c|c|c|c|c|c|c|c|c|c|}
\hline Irish Creek 2s & 10 & 8.5 & 4.5 & 10 & 0 & 0 & 33 & High & 39.5 & High \\
\hline Irish Creek 3p & 10 & 2.5 & 3.5 & 10 & 0 & 0 & 26 & Moderate & 35 & High \\
\hline Irish Creek 3s & 9 & 2.5 & 3.5 & 10 & 0 & 0 & 25 & Moderate & 32 & High \\
\hline
\end{tabular}

Note: Symbols used are as follows; $\mathrm{SBH}$ :BkfH is Study Bank Height ratio, WV is woody vegetation present, BA is bank angle, SP is surface protection, BMA is bank material adjustment, SA is stratification adjustment. A "p" denotes pool cross-section study bank while "s" denotes representative study bank.

As noted in Table 8, 13 of the 18 study banks changed BEHI ratings. Of those, 11 adjective ratings decreased while two increased in erosion hazard. Figure 13 illustrates the changes to the predictive erosion curves utilizing the new BEHI ratings according to vegetation adjacent to the streambank.

Figure 13. Adjusted BEHI-NBS erosoin prediction curves for Northeast Kansas. Vegetation modification of 2.5 or 8.5 is included in this edition of curves. Moderate BEHI (Blue) $R^{2} 0.88$ (6 data points) while High BEHI (Magenta) $R^{2} 0.84$ (9 data points) Low (1 data point).

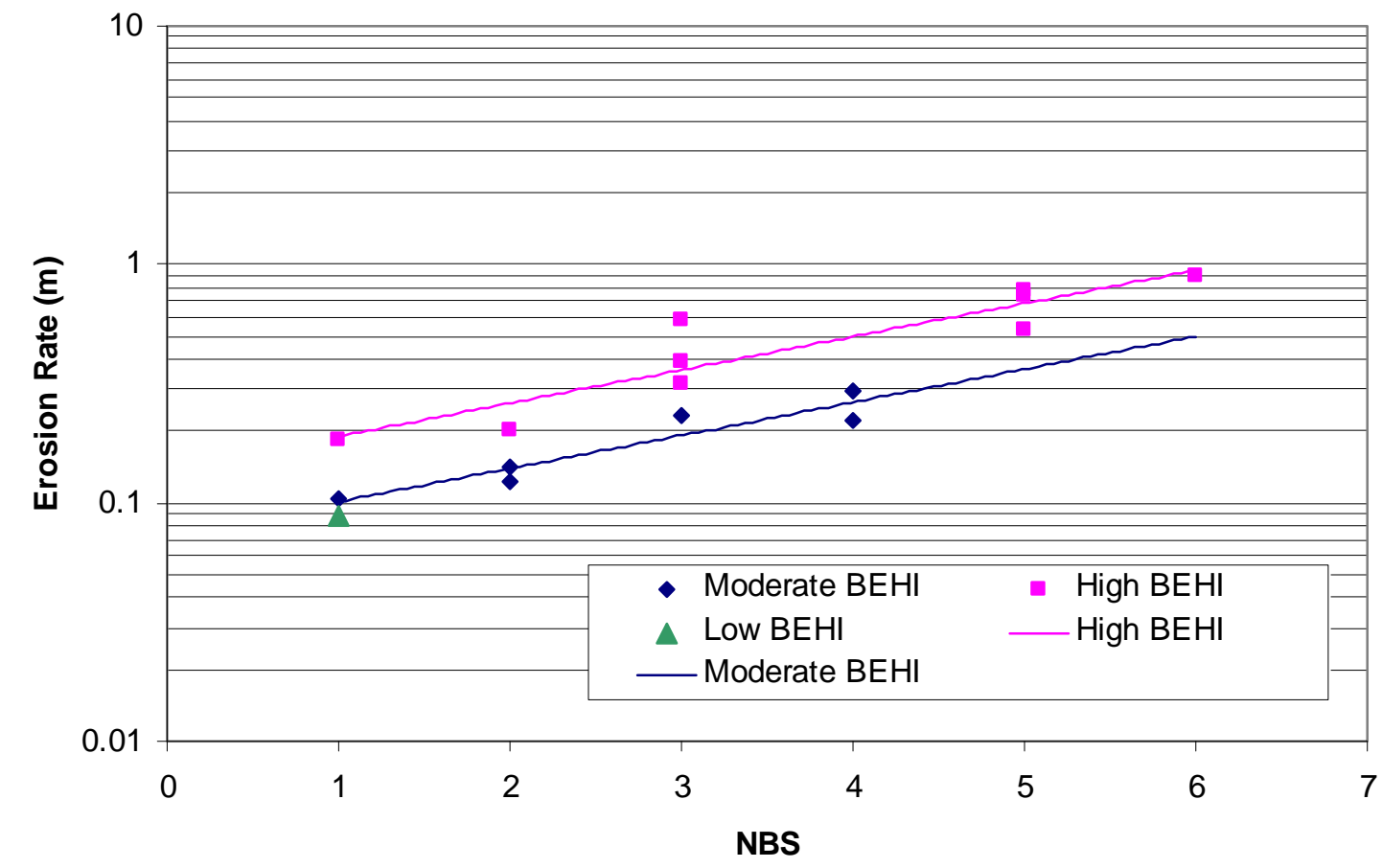

Note: High BEHI slope $: \mathrm{y}=0.1378 \mathrm{e}^{0.3213 x}$; Moderate BEHI slope $: \mathrm{y}=0.0736 \mathrm{e}^{0.3195 \mathrm{x}}$.

\section{Summary}

As noted, the original erosion prediction curves developed in this study displayed more variation than the Yellowstone, Colorado, Piedmont, or Arkansas curves. Runoff delivery and timing differences between Northeast Kansas and the mountainous regions of Yellowstone, Colorado, and North Carolina lead to discharge differences perhaps creating more episodic and sporadic erosion in Northeast Kansas. In addition, bank material and woody vegetation controls may play a larger role in Northeast Kansas than other regions. Vegetation seems to play a vital role in maintaining bank stability in this 
region of Northeast Kansas. Assessing the original BEHI-NBS erosion prediction curves for Northeast Kansas illustrated something was not being accounted for, or not counted for enough, in our application of the model. Low $\mathrm{R}^{2}$ values along with inverted expected erosion rates confirmed this notion. Erosion rates then plotted against both BEHI score and NBS rating with each site's woody vegetation cover showed a clustering of sites with woody vegetation versus sites without. Thus, the vegetation portion of the BEHI was modified and simplified, which resulted in consistent $\mathrm{R}^{2}$ values and correct order of the BEHI adjective ratings. Masterman and Thorne (1992) stated streams with a W:D ratio less than 16 were subject to vegetation controls more so than streams with a higher ratio. All study stream reaches in the Black Vermillion have a W:D ratio less than 13.5. These streams are currently in a state of transition regarding stream evolutionary sequence, moving from degradation of the stream bed to deposition and widening through accelerated bank erosion processes. It is anticipated that streams will continue to erode at high rates for some time.

It is evident more studies should be completed to determine dominant processes of streambank erosion and associated controlling variables dictating bank shear strength in given hydrophysiographic regions. Once these studies begin to untangle the different processes and controlling variables for given regions, we can modify the current BANCS model or develop new models for better predictability of bank erosion in those regions. Nevertheless, our predictive capacity regarding erosion of streambank material is furthered from this study and has set precedent for modifying the BEHI portion of the BANCS model, which is utilized by many state and federal agencies. As suggested previously, there may be more than one factor controlling streambank erosion rates in a given region. This study demonstrated that vegetation plays a vital role in influencing erosion rates in Northeast Kansas. However, bank materials may also play a vital role, as these soils are high in clay content that may act similar to bedrock when wetted. Complex groundwater flow through buried channels, tile drainage, and ephemeral gullies in this highly modified agricultural landscape make modeling and prediction of streambank erosion difficult and challenging at best.

Currently, we are conducting detailed analyses of the bank material samples from all nine of our study reaches in the Black Vermillion River Basin. For while our modifications of the vegetation components of the BEHI model allowed us to more accurately predict/model bank erosion rates in Northeast Kansas, these modifications make it more difficult for our data to join the base of data collected by others in other hydrophysiographic provinces.

Rosgen (personal communication, 2011), who developed the BANCS model, suggested that a bank material adjustment for our high clay content and highly cohesive soils might be a more appropriate modification of the BEHI rating. A materials adjustment would allow field observers/researchers to employ their experience and judgment while allowing data collected to more easily join with the growing base of information gathered employing the current BANCS model. We are investigating the possibility of setting threshold clay content percentages for subtracting BEHI points in our bank material adjustments. The next step will be to develop a rapid, easily employed field 
test/observation to distinguish such clay content thresholds and to assess and assign points and ratings accordingly. Our work on this bank materials adjustment modification will be reported in a subsequent work (in process) detailing channel changes in the Black Vermillion River of Northeast Kansas.

\section{Acknowledgements}

We would like to thank the USDA-CSREES program (grant \# KS600399) for their funding and support and the NRCS in Salina Kansas for supplemental materials. We would also like to thank Dr. Philip Barnes, Professor Stephanie Rolley and Professor Richard Hoag for their support and input. In addition, we would like to thank those graduate students who helped with data collection and private landowners for allowing us access to their property. Finally, our sincere thanks to three anonymous reviewers whose input greatly improved this report. 
Literature Cited

Aber, J. S. (2007a). Geology, geomorphology and geohydrology of the Flint Hills: East central Kansas. Emporia, Kansas: Emporia State University, Earth Science Department.

Aber, J. S. (2007b). Geohydrology of the Flint Hills: East central Kansas. Emporia, Kansas: Emporia State University, Earth Science Department.

Beach, T. (1994). The fate of eroded soil: Sediment sinks and sediment budgets of agrarian landscapes in Southern Minnesota, 1851-1988. Annals of the Association of American Geographers. 8 (1), 5-28.

Boggess, W., Miranowski, J., Alt, K., and Heady, E. (1980). Sediment damage and farm production costs: A multiple-objective analysis. North Central Journal of Agricultural Economics. 2 (2), 107-112.

Bull, L. J. (1997). Magnitude and variation in the contribution of bank erosion to the suspended sediment load of the River Severn, UK. Earth Surface Processes and Landforms. 22 (12), 1109-1123.

Evans, D. J., Gibson, C. E., and Rossell, R. S. (2006). Sediment loads and sources in heavily modified Irish catchments: A move towards informed management strategies. Geomorphology. 79 (1-2), 93-113.

Fox, G. A., Wilson, G. V., Simon, A., Langendoen, E. J., Akay, O., and Fuchs, J. W. (2007). Measuring streambank erosion due to ground water seepage: Correlation to bank pore water pressure, precipitation and stream stage. Earth Surface Processes and Landforms. 32, 1558-1573.

Genet, M., Stokes, A., Salin, F., Mickovski, S. B., Fourcaud, T., Dumail, J-F., et al. (2005). The influence of cellulose content on tensile strength in tree roots.

Plant and Soil, 278, 1-9.

Gurnell, A. (1997). The hydrological and geomorphological significance of forested floodplains. Global Ecology and Biogeography Letters, 6, 219-229.

Grissenger, E. H. (1982). Bank erosion of cohesive materials. Gravel Bed Rivers. Hey, R. D., Bathurst, J. C. and Thorne, C. R. (eds.) John Wiley and Sons, Ltd., New York, New York, pp 273-287.

Hargrove, B. L., Johnson, D., Snethen, D. and Middendorf, J. (2010). From Dust Bowl to Mud Bowl: Sedimentation, conservation measures, and the future of reservoirs. Journal of Soil and Water Conservation. 65 (1), 14A-17A.

Jennings, G. D. and Harman, W. A. (2001). Measurement and stabilization of streambank erosion in North Carolina. Soil Erosion Research for the $21^{\text {st }}$ Century, Proc. Int. Conf. (3-5 January 2001, Honolulu, Hawaii. Eds. J. C. Ascough II and D. C. Flanagan. ASAE publication number 701P0007.

Knighton, David. (1998). Fluvial Forms and Processes. London, England: Arnold Publishers.

Lawler, D. M. (1995). The impact of scale on the processes of channel-side sediment supply: a conceptual model. Effects of Scale on Interpretation and Management of Sediment and Water Quality. 226, 175-184.

Masterman, R. and Thorne, C. R. (1992). Predicting influence of bank vegetation on channel capacity. Journal of Hydraulic Engineering. 118 (7), 1052-1058.

doi 10.1061/(ASCE)0733-9429(1992)118:7(1052). 
Naiman, R. J., and Decamps, H. (1997). The ecology of interfaces: Riparian Zones. Annual Review of Ecology and Systematics, 28, 621-658.

Odum, E. P. (1971). Fundamentals of Ecology (3rd Ed.). W. B. Saunders Company, Philadelphia, PA.

Oznet (2008). Report of the Kansas State Board of Agriculture: Climate of Kansas. http://www.oznet.ksu.edu/wdl/climate/cok/index.asp. Topeka, KS: Author.

Pollen, N. (2007). Temporal and spatial variability in root reinforcement of streambanks: Accounting for soil shear strength and moisture. Catena, 69, 197-205.

Riley Ann L. (2008, January). Putting a price on riparian corridors as water treatment facilities. Paper presented at Regional Water Quality Control Board, Oakland, CA., Jan. 2008.

Ringler, N. H. and Hall, J. D. (1975). Effects of logging on water temperature and dissolved oxygen in spawning beds. Transactions of the American Fisheries Society. 104, 111-121. DOI: 10.1577/1548-8659(1975)104<111:EOLOWT>2.0.CO;2.

Rogers, P. (2008). Facing the freshwater crisis. Scientific American. 299 (2), 4653.

Rosgen, D. (1996). Applied River Morphology ( $\left.2^{\text {nd }} e d\right)$. Wildland Hydrology, Pagosa Springs, CO.

Rosgen, D. (2001). A practical method of computing streambank erosion rate. Proceedings of the Seventh Federal Interagency Sedimentation Conference. March 2529, 2001, Reno, NV. Vol. 2.

Rosgen, D. (2006). Watershed Assessment of River Stability and Sediment Supply (WARSSS). Wildland Hydrology, Fort Collins, CO.

Rosgen, D. (2008a). River Stability Field Guide. Wildland Hydrology, Fort Collins, CO.

Rosgen, D. (2008b). River Stability Forms and Worksheets. Wildland Hydrology, Fort Collins, CO.

Schumm, S. A. (1973). Geomorphic thresholds and complex response of drainage systems. Fluvial Geomorphology, In: M. Morisawa (Editor). Binghamton, New York. 299-309.

Sekely, A. C., Mulla, D. J., and Bauer, D. W. (2002). Streambank slumping and its contribution to the phosphorus and suspended sediment loads of the Blue Earth River, Minnesota. Journal of Soil and Water Conservation. 57 (5), 243-250.

Simon, A. and Darby, S. E. (1999). The nature and significance of incised river channels. Incised River Channels: Processes, Forms, Engineering and Management. Darby, S. E. and Simon, A. (eds.). Wiley, Chichester, UK; 1-18.

Thorne, C. R. (1990). Effects of vegetation on riverbank erosion and stability. Vegetation and Erosion: Processes and Environments, Thornes, J.B. (Editor). John Wiley \& Sons Ltd. West Sussex, England.

Thorne, C. R. (1999). Bank processes and channel evolution in the incised rivers of North-central Mississippi (97-121). Incised River Channels, Darby, S. E. \& Simon, A. (Eds.). John Wiley \& Sons Ltd. West Sussex, England.

United States Army Corps of Engineers (US-COE). (2011). Tuttle Creek Lake Information Website. http://www.nwk.usace.army.mil/tc/TheLake.cfm

U. S. Department of Agriculture: Forest Service. (Dec. 28, 2010). Climate change and water; Perspectives from the Forest Service. Web site 
http://www.fs.fed.us/ccrc/files/CC\%20and\%20Water\%20In\%20Brief.pdf U. S. Department of Agriculture: Natural Resources Conservation Service. (2011). Web Soil Survey. http://websoilsurvey.nrcs.usda.gov/app/HomePage.htm U. S. Environmental Protection Agency (US-EPA). (2009). National water quality inventory: 2000 report (EPA-841-R-02-001). web site www. epa.gov/305b.

Van Eps, M. A., Formica, S. J., Morris, T. L., Beck, J. M., and Cotter, A. S. (2004). Using a Bank Erosion Hazard Index (BEHI) to estimate annual sediment loads from streambank erosion in the West Fork White River Watershed. Proceedings of the 12-15 September 2004 ASAE Conference. St. Paul, MN, September 12, 2004. J. C. D’Ambrosio, editor. ASAE publication number 701P0904.

Walters, K. L. (1954). Geology and Ground-water Resources of Marshall County, Kansas. Kansas Geological Survey Bulletin 106 (website). http://www.kgs.ku.edu/General/Geology/Marshall/index.html. Kansas: Author. Williams, J. and Smith, C. (2008). Economic issues of watershed protection and reservoir rehabilitation. Sedimentation in Our Reservoirs: Causes and Solutions. Kansas Water Office, Kansas Water Resources Institute, Kansas Center for Agricultural Resources and the Environment, Kansas State University Agricultural Experiment Station and Cooperative Extension Service. Manhattan, Kansas.

Wynn, T. M. and Mostaghimi, S. (2006). The effects of vegetation and soil type on streambank erosion, Southwestern Virginia, USA. Journal of the American Water Resources Association. 42 (1), 69-82. 